\title{
RISK FACTORS OF HEPATITIS B INFECTION AMONG PATIENTS IN A TERTIARY CARE SETTING IN KERALA
}

N. Premaletha ${ }^{1}$

1 Professor and HOD, Department of Gastroenterology, Government Medical College, Kottayam, Kerala.

\begin{tabular}{l}
\hline ABSTRACT \\
\hline BACKGROUND \\
High prevalence of blood-borne pathogens is a public health problem in developing countries like India and among them HBV is the \\
most infectious one. There is a scarcity of studies in Kerala regarding the socioeconomic and personal, behavioural, health care and \\
other related factors. \\
The objective of this study is to find out the determinants of transmission of hepatitis B in outpatients attending OP clinic in \\
Medical Gastro Department in Medical College.
\end{tabular}

\section{MATERIALS AND METHODS}

Patients of hepatitis B in Gastroenterology Medical Unit 1 were interviewed, and data was collected using a structured proforma. At 95\% confidence interval, the sample size was calculated as 310 and 391 cases and 109 controls. Statistical analysis was done using SPSS version 13 .

Design- A case-control study.

Place and Duration of the Study- In OP clinic in Medical Gastroenterology Department, Medical College, Thiruvananthapuram, Kerala during $2012-13$.

\section{RESULTS}

The determinant of transmission of Hepatitis B was found statistically significant which included sex, religion, socio-economic status, education, 'other related risk factors' which include earlier infection of HBV, being diabetic and family history of hepatitis infection.

\section{CONCLUSION}

There is a need to create awareness about determinants and transmission of Hepatitis B in Kerala. The vaccination against Hepatitis B should be strongly recommended for high risk groups like family history of infection. Majority of the respondents are not immunized. Since the disease is highly infective but preventable, awareness and prevention are factors of importance.

\section{KEYWORDS}

Determinants, Hepatitis B, Transmission.

HOW TO CITE THIS ARTICLE: Premaletha N. Risk factors of hepatitis B infection among patients in a tertiary care setting in Kerala.

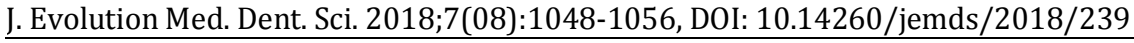

\section{BACKGROUND}

High prevalence of blood-borne pathogens is a public health problem in developing countries like India. Among them, HBV is the most infectious one. It is considered as one of the major causes of acute and chronic liver diseases worldwide, accounting for over 360 million cases of chronic hepatitis and 620,000 deaths per year. ${ }^{1} \mathrm{HBV}$ is reported to be responsible for 70 percent of cases of chronic hepatitis and 80 percent of cases of cirrhosis of the liver. About 80 percent of Indian patients with hepatocellular carcinoma have hepatitis virus associated liver disease. ${ }^{2}$ In majority of individuals, complications are not experiencing but 15 to 40 percent have serious sequelae of cirrhosis and HCC. The spectrum of chronic HBV infection ranges from the 'inactive carrier state' to chronic hepatitis B (e Ag -ve or e Ag +ve), cirrhosis, hepatocellular carcinoma (HCC) and end stage liver disease (ESLD) requiring liver transplantation.

'Financial or Other Competing Interest': Dr. Narayanana reports grants from SBMR Fund, during the conduct of the study.

Submission 18-07-2017, Peer Review 11-11-2017,

Acceptance 19-12-2017, Published 19-02-2018.

Corresponding Author:

Dr. N. Premaletha,

TC/2/379(6), 'Deepthi' Doctor's Garden, Ulloor,

Medical College P. $O$,

Trivandrum-695011, Kerala.

E-mail: drpremalathasunil@gmail.com

DOI: $10.14260 /$ jemds $/ 2018 / 239$

\section{(c) (i)}

On the basis of endemicity of HBV infection countries are classified into high (> 8\%) like South East Asia, China etc.; intermediate $(2 \%-7 \%)$ like Eastern Europe or low $(<2 \%)$ incidence countries like USA, Australia etc. ${ }^{3}$ India has intermediate endemicity of Hepatitis B with Hepatitis B surface antigen (HBsAg) prevalence between $2 \%$ and $10 \%$ among populations studied. Roughly, a tenth of the total global load resides in India.4,5 The number of HBsAg carriers in India has been estimated to be over 400 million. According to WHO in India of the 25 million infants born every year, over one million run the lifetime risk of developing chronic HBV infection. Estimates indicate that annually over 100,000 Indians die due to illness related with HBV infection. In community prevalence study from Tamilnadu, 6 the HBsAg prevalence was 5.7 percent with 23.5 percent of these having positive HB e-antigen. Through a systematic review of literature, it is concluded that the true prevalence of Hepatitis $\mathrm{B}$ in non-tribal populations in India is $2.4 \%$ and true prevalence among tribal populations is $15.9 \%{ }^{7}$

Transmission occurs in all age groups associated with percutaneous and permucosal exposure to infectious body fluids from persons with acute or chronic HBV infection. The highest concentrations of HBV occur in blood and serous fluids, and infection most frequently occurs through direct inoculation of the virus through unsafe injections or reuse of contaminated medical equipment. Other common modes of transmission include sexual contact with infected persons and births from HBV-infected mothers. 8,9 
It is found in a study 10 that a higher rate of HBsAg is among men than women. Age is associated with the prevalence found among many studies.6,11 Lower socioeconomic group, low level of education and poverty are found to be factors of higher prevalence of HBV.10,11 Use of reusable glass syringes, being shaved by a community barber and being born at home were associated with heightened transmission of HBV in West Bengal. ${ }^{11}$ Studies in other countries ${ }^{12}$ also found age, socioeconomic status, occupations like health care workers, barbers, business owners with frequent travels, sex workers and sanitary workers, reuse of syringes, surgical and dental procedures, caesarean section in females, accidents and blood loss, parenteral drugs and drips, IV drug abuse, ear and nose piercing, tattooing, getting shave and hair cut from barbers, sharing of tooth brush, contact and family history of hepatitis, extramarital sex, lack of knowledge about transmission of Hepatitis, and non-practicing of active and passive immunization to be significant determinants of transmission of Hepatitis B. In Taiwan, one study ${ }^{13}$ reported that infection was found to be inversely related to educational level and to be directly related to the frequency of the receipt of parenteral injection for medical purposes. Risk factors for HBsAg positivity were gender, age above 50 years and a family history of hepatocellular carcinoma. HBV seropositivity was significantly associated with married status, history of jaundice, surgical operations, needle-stick injuries, visiting unregistered healthcare providers, receiving treatment for sexually transmitted diseases, animal bites; ear-nose-body piercing in females; circumcision and visiting community barber for shaving in males. Married status, surgical operations, animal bites, visiting unregistered health-care providers; and ear-nose-body piercing in females were significantly associated with HBV-seropositivity as revealed through logistic regression analysis. ${ }^{14}$

In these backgrounds, it is proposing to undertake a study aimed at understanding hepatitis B infection by biomedical testing determining infectivity by transfusion or by sociodemographic factors. The implementation of a comprehensive public health response to hepatitis B in Kerala is urgently required to reduce the increasing burden of hepatitis $B$ infection on the health system and the community. A significant gap in knowledge of the diseases and the public health issues due to hepatitis B is evident in Kerala, as there are limited studies regarding these. Hence, it is necessary in understanding of how people infect with hepatitis. Hence, the objectives of the study are:

\section{Objectives}

1. To compare the demographic and socioeconomic factors of HBsAg positive (cases) and negative (controls) patients attending the Gastroenterology Department of Medical College, Thiruvananthapuram.

2. To find out the risk factors of Hepatitis B infection.

\section{MATERIALS AND METHODS}

\section{Study Design}

We conducted a case control study among patients attending the Gastroenterology Department of Government Medical College, Thiruvananthapuram, the capital district of Kerala. It is a super speciality hospital and hence the patients from the peripheral areas of the state and neighbouring states are coming here.

Data were collected after getting written consent from the respondents. Information collected includes background demographic, socio-economic and health aspects.

\section{Sample Patients}

Based on a pilot study done in the selected department, we have calculated the sample size as follows: $n=z^{2} p q / d^{2}$ where $\mathrm{n}=$ sample size, $\mathrm{z}=$ standard deviation $(1.96), \mathrm{p}=$ prevalence, $\mathrm{q}=$ 1-p and $d=$ degrees of freedom (0.05), and assuming a prevalence of $13 \%$ based on the most recent Hepatitis $B$ surface Antigen prevalence for the study setting which is a super speciality hospital. At $95 \%$ confidence level, the sample size is calculated to be 434 . Hence, the final sample size is fixed as 500 . We conducted the survey for three months during 2012. Since the hospital we selected is a referral one, more cases than controls are seen. The patients coming to the hospital are mostly referred from other hospitals in Thiruvananthapuram district and nearby districts and Tamilnadu state. So mostly the serious cases are referred to the hospital and hence the chance to be positive HBsAg is higher. Thus, during the period we got a total sample of 500, of which 109 are controls and 391 are cases. Case group are those who are found positive for HBsAg. Controls are identified from the patients attending same OP with any diagnosis other than hepatitis and with no jaundice on the same day of confirmation of diagnosis of the HBV case patients. Hence, it is a case-control study. Besides socio-demographic variables, the variables associated with risk factors included reuse of the syringes, blood transfusion, surgical procedure, dental procedure, accident and blood loss, parenteral drugs and drips, ear and nose piercing, tattooing, getting shaved and hair cut from barbers, sharing of tooth brush, family history of hepatitis, extramarital sexual contacts and immunization against Hepatitis B.

Risk factors were grouped into three categories based on exposure patterns. The first group included exposures associated with health care, such as receiving a blood transfusion, receiving an injection, visiting a dentist and exposure to any invasive procedure during the last 6 months including surgery, dialysis, wound and accidents. The second group of exposures included personal practices that might be associated with infection such as extra or premarital relationship, being shaved at a community barber and drug use, consumption of alcohol and smoking. The third group of risk factors included other risk factors such as being diabetic, having household contacts with hepatitis and have an earlier infection and being immunized.

Univariate and multivariate analyses were conducted and logistic regression is performed to identify risk factors independently associated with the risk of acquiring disease. Final step of Backward LR method of Logistic regression is interpreted as risk factors. Data analysis was done through SPSS version 13. For variables that might influence the occurrence of acute HBV, we calculated odds ratios (OR) and the P-value of $<0.05$ is considered statistically significant. Ninety-five percent confidence limits of values are calculated. 


\section{Socio-economic and Demographic Background of the Patients}

Understanding socio-demographic characteristics of the patients is necessary for identifying the determining factors of HBV. Age group differentiation among cases and controls shows that about equal percent of all age groups except old age groups. Mean age of the patients is 42.6 years (13 - 87 years) with standard deviation of 13.5 at $95 \%$ confidence interval. HBV patient and controls are not differentiated in their age, because mean age of both are almost equal. Among the patients, about 68 percent are males. More than 72 percent of HBV patients are males, whereas almost equal percent are males and females in the control group. As resemblance to the general population of Kerala, Hindus form 64 percent of the respondent population and about 19 percent are Christians and about 18 percent are Muslims. Cases (HBV patients) and control (with HBsAg negative) shows that less than 10 percent in the control group belonging to Muslims, whereas in case group 20 percent are Muslims. Christians in the two groups are almost equal. Hindus are higher in control group. Place of residence of the total respondents shows that about 27 percent belonging to urban and about 66 percent belonging to rural and another 6.4 percent are from coastal areas. Case group with HBsAg positive shows that patients from rural areas are more attending in $\mathrm{OP}$, whereas in control group patients from urban areas are more. Type of house they live is the only variable to show the status of their living. Houses are classified as pucca, semi-pucca and kutcha according to their own perception. It shows that about 48 percent belong to pucca house, 32 percent reported their house as semi-pucca.
While more than 68 percent of the control group reported their houses as pucca and about 9 percent of their houses as kutcha, more than one-fourth of the HBV patients reported they are in the lower socioeconomic strata. Educational analysis of the two groups shows that professionally educated and graduated are more in control group than in case group. Occupational analysis reveals that about an equal percent (about 13 percent) of the respondents are distributed in service categories such as professional and semi-professional and clerical. Percent of unskilled worker is also same. Control (with HBsAg negative) and case group are not widely differentiated. Patients of all occupational groups utilize government facilities, especially super speciality in the Medical Colleges. Among those patients who attended OP, 10 percent are diabetic. Control (with HBsAg negative) group has more percent of diabetic patients than cases group (15.6 vs. 8.4). Among the respondents, about 35 percent are consuming alcohol. Out of the alcoholic, about 60 percent are daily consuming it. About 28 percent are smoking tobacco and 64.5 percent are using it on a daily basis. Drug use is reported by 1.6 percent of the respondents. Among HBV patients, two percent of the patients are drug users, 38.6 are alcoholic and about 30 percent are smokers. Percent of consuming alcohol, smoking and drug use is less among controls. Immunization status of the total patients is 7.2 percent. HBV cases are not immunized at all and 33 percent of the control group is immunized. Earlier infection if any when asked is reported by 25.3 percent of the cases with HBsAg positive patients and 6.4 percent of the control group.

\begin{tabular}{|c|c|c|c|}
\hline \multicolumn{2}{|c|}{ Characteristics } & Cases with HBsAg Positive & Control with HBsAg Negative \\
\hline \multirow{7}{*}{ Age } & $\leq 20$ & 3.1 & 2.8 \\
\hline & $21-30$ & 17.6 & 14.7 \\
\hline & $31-40$ & 25.6 & 27.5 \\
\hline & $41-50$ & 30.2 & 28.4 \\
\hline & $51-60$ & 16.6 & 12.8 \\
\hline & $61-70$ & 3.3 & 9.2 \\
\hline & $>70$ & 3.6 & 4.6 \\
\hline \multicolumn{2}{|c|}{ Age (mean \pm SD) } & $42.3 \pm 13.4$ & $43.5 \pm 13.65$ \\
\hline \multirow{2}{*}{ Sex } & Male & 72.6 & 53.2 \\
\hline & Female & 27.4 & 46.8 \\
\hline \multirow{3}{*}{ Religion } & Hindu & 61.1 & 73.4 \\
\hline & Muslim & 19.9 & 9.2 \\
\hline & Christian & 18.9 & 17.4 \\
\hline \multirow{4}{*}{ Caste } & SC/ST & 8.7 & 10.1 \\
\hline & OBC/OEC & 52.2 & 47.7 \\
\hline & Forward & 21.5 & 28.4 \\
\hline & Others & 17.6 & 13.8 \\
\hline \multirow{3}{*}{ Residence } & Urban & 25.1 & 35.8 \\
\hline & Rural & 68.5 & 57.8 \\
\hline & Coastal & 6.4 & 6.4 \\
\hline \multirow{7}{*}{ Education } & Professional & 2.6 & 5.5 \\
\hline & Graduation & 10.2 & 24.8 \\
\hline & Intermediate & 18.7 & 11.9 \\
\hline & High school & 39.4 & 32.1 \\
\hline & Middle school & 19.7 & 8.3 \\
\hline & Primary & 7.7 & 13.8 \\
\hline & Illiterate & 1.8 & 3.7 \\
\hline \multirow{3}{*}{ Type of House } & Pucca & 41.9 & 68.8 \\
\hline & Semi Pucca & 34.5 & 22.0 \\
\hline & Kutcha & 23.5 & 9.2 \\
\hline \multirow{2}{*}{ Occupation } & Professional & 13.0 & 13.8 \\
\hline & Semi professional & 11.3 & 9.2 \\
\hline
\end{tabular}




\begin{tabular}{|c|c|c|c|}
\hline & Clerical & 12.5 & 14.7 \\
\hline & Skilled Worker & 16.1 & 19.3 \\
\hline & Semi-skilled worker & 18.2 & 8.3 \\
\hline & Unskilled worker & 12.3 & 16.5 \\
\hline & Unemployed & 16.6 & 18.3 \\
\hline \multirow{2}{*}{ Diabetic } & Yes & 8.4 & 15.6 \\
\hline & No & 91.6 & 84.4 \\
\hline \multirow{2}{*}{ Drug Use } & Yes & 2.0 & 0 \\
\hline & No & 98.0 & 100.0 \\
\hline \multirow{2}{*}{ Alcohol Consumption } & Yes & 38.6 & 23.9 \\
\hline & No & 61.4 & 76.1 \\
\hline \multirow{3}{*}{ Frequency } & Daily & 45.7 & 65.4 \\
\hline & Sometimes & 50.3 & 26.9 \\
\hline & Rarely & 4.0 & 7.7 \\
\hline \multirow{2}{*}{ Smoking } & Yes & 29.9 & 22.0 \\
\hline & No & 70.1 & 78.0 \\
\hline \multirow{3}{*}{ Frequency } & Daily & 64.1 & 70.8 \\
\hline & Sometimes & 32.5 & 25.0 \\
\hline & Rarely & 3.4 & 4.2 \\
\hline \multirow{2}{*}{$\begin{array}{c}\text { Extra/Premarital } \\
\text { Relationship }\end{array}$} & Yes & 4.1 & 1.8 \\
\hline & No & 95.9 & 96.4 \\
\hline \multirow{2}{*}{$\begin{array}{c}\text { Immunization Status } \\
\text { against HBV }\end{array}$} & Yes & 0 & 33.0 \\
\hline & No & 100 & 67.0 \\
\hline \multirow{2}{*}{ Earlier Infection HBV } & Yes & 25.3 & 6.4 \\
\hline & No & 74.7 & 93.6 \\
\hline Total & & $391(78.4)$ & $109(21.6)$ \\
\hline
\end{tabular}

\section{Exposure to Risk of Patients}

To know the route of transmission, it is important to identify the risk factors. Hence, this section aims to identify the differentials of known risk factors among cases and controls.

Earlier infection of HBV is reported by only 21.2 percent of the respondents. They were asked about their history of blood contact for finding the risk. Total respondents who had exposed the risk factors are depicted in Figures 3.1, 3.2, 3.3 and 3.4. About 86 percent had undergone blood investigation. Out of these people, about 66 percent did their blood investigation within six months. Only 35 percent reported that they used a disposable syringe always in their investigation and 27.5 percent used disposable syringe sometimes. More than 45 percent of the patients received injection of any kind. Out of these, 58 percent done it within six months. And only about 36 percent ascertained the use of a disposable syringe. About 30 percent had a blood transfusion of any reason and 64 percent did it within six months. About 14 percent ever had donated blood and about 27 percent had met an accident and blood loss in their life. More than 40 percent of the patients had undergone surgical procedure, out of which about 23 percent was within six months. Only 1.6 percent of patients had a history of renal dialysis. Dental procedure is done by 40 percent and only 11 percent did it within six months. Only 46 percent received parenteral drugs and drips. More than half of the patients had a hair cut in barber shop. Only 4.5 percent shared a razor and 1.8 percent had shared tooth brush in their life. Ear piercing or tattooing was done by 6.6 percent. Ear piercing is mainly reported by women patients. An enquiry on the prevalence of HBV among the family members revealed that 27 percent had family history. Only 2.0 percent had the family history of carcinoma. Extra marital relationship is a risk factor of Hepatitis B, although only 16.4 percent reported that they had an extra marital relationship.

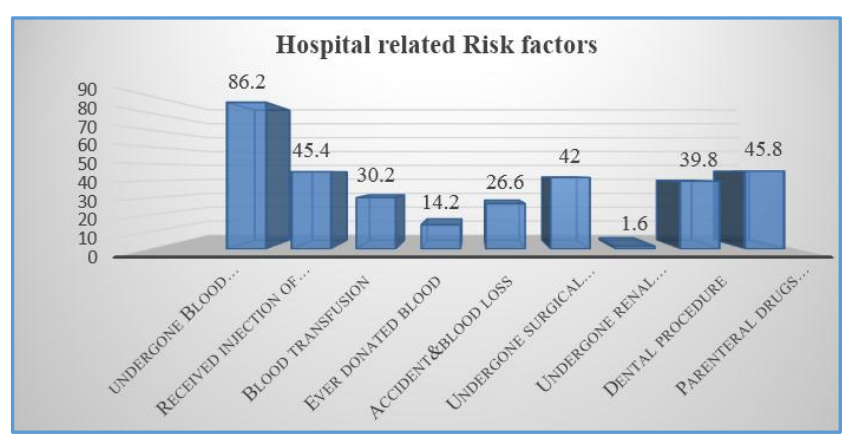

Figure 1. Hospital or Health Care Related Risk Factors of Respondents

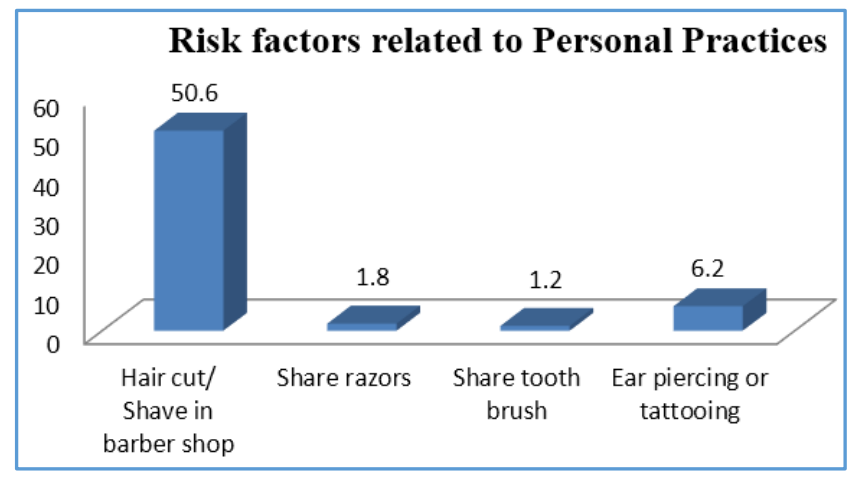

Figure 2. Exposure of Personal Practices of Risk Factors 


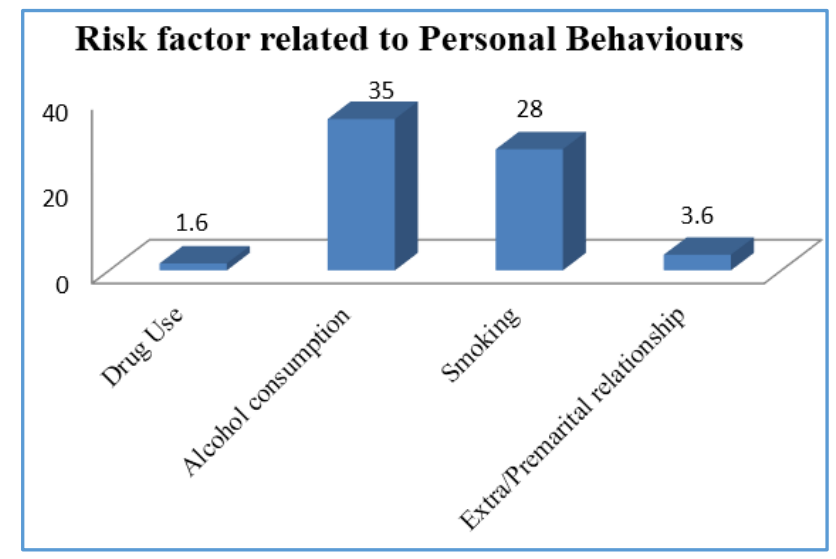

Figure 3. Exposure to Personal Behavioural Risk Factors

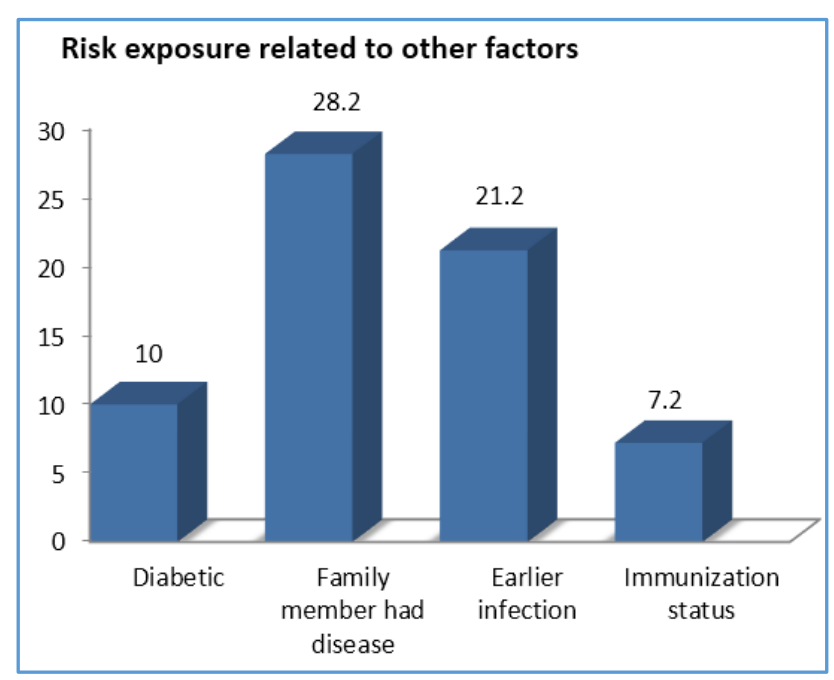

Figure 4. Risk Factors to other Related Factors

\begin{tabular}{|c|c|c|c|c|}
\hline \multirow{2}{*}{\multicolumn{2}{|c|}{ Risk Factors }} & \multicolumn{2}{|c|}{ HBsAg Status } & \multirow{2}{*}{ Tota } \\
\hline & & Positive & Negative & \\
\hline \multicolumn{5}{|c|}{ Hospital or Health Care Related Risk Factors } \\
\hline \multirow{2}{*}{$\begin{array}{l}\text { Undergone } \\
\text { blood } \\
\text { investigation }\end{array}$} & \begin{tabular}{|c|} 
Yes \\
\end{tabular} & 84.4 & 92.7 & 431 \\
\hline & No & 15.6 & 7.3 & 69 \\
\hline \multirow{2}{*}{$\begin{array}{l}\text { When blood } \\
\text { investigation }\end{array}$} & Within six months & 62.4 & 74.3 & 287 \\
\hline & Before six months & 37.7 & 18.3 & 144 \\
\hline \multirow{3}{*}{$\begin{array}{c}\text { Whether } \\
\text { disposable } \\
\text { syringe used }\end{array}$} & Always & 26.7 & 59.4 & 148 \\
\hline & Sometimes & 33.3 & 10.9 & 121 \\
\hline & No & 40.0 & 29.7 & 162 \\
\hline \multirow{2}{*}{$\begin{array}{l}\text { Received } \\
\text { injection of } \\
\text { any kind }\end{array}$} & Yes & 41.7 & 57.8 & 226 \\
\hline & No & 58.3 & 42.2 & 274 \\
\hline \multirow{2}{*}{$\begin{array}{l}\text { When } \\
\text { received } \\
\text { injection }\end{array}$} & Within six months & 60.1 & 54.0 & 132 \\
\hline & Before six months & 39.9 & 46.0 & 94 \\
\hline \multirow{3}{*}{$\begin{array}{l}\text { Ascertained } \\
\text { disposable } \\
\text { syringe }\end{array}$} & Always & 25.2 & 60.3 & 79 \\
\hline & Sometimes & 12.3 & 7.9 & 25 \\
\hline & No & 62.6 & 31.7 & 122 \\
\hline \multirow{2}{*}{$\begin{array}{c}\text { Blood } \\
\text { transfusion of } \\
\text { any reason }\end{array}$} & Yes & 31.7 & 24.8 & 151 \\
\hline & No & 68.3 & 75.2 & 349 \\
\hline \multirow{2}{*}{$\begin{array}{l}\text { When Blood } \\
\text { transfusion }\end{array}$} & Within six months & 50.0 & 25.9 & 69 \\
\hline & Before six months & 50.0 & 74.1 & 82 \\
\hline \multirow{3}{*}{\begin{tabular}{|c|}
$\begin{array}{c}\text { Ever donated } \\
\text { blood }\end{array}$ \\
\end{tabular}} & Yes & 13.6 & 16.5 & 71 \\
\hline & No & 86.4 & 83.5 & 429 \\
\hline & Within six months & 56.6 & 77.8 & 44 \\
\hline
\end{tabular}

\begin{tabular}{|c|c|c|c|c|}
\hline $\begin{array}{c}\text { When Blood } \\
\text { donation }\end{array}$ & Before six months & 43.4 & 22.2 & 27 \\
\hline \multirow{2}{*}{$\begin{array}{l}\text { Accident and } \\
\text { blood loss }\end{array}$} & Yes & 30.7 & 11.9 & 133 \\
\hline & No & 69.3 & 88.1 & 367 \\
\hline \multirow{2}{*}{$\begin{array}{c}\text { When } \\
\text { accident }\end{array}$} & Within six months & 46.7 & 15.4 & 58 \\
\hline & Before six months & 53.3 & 84.6 & 75 \\
\hline \multirow{2}{*}{$\begin{array}{l}\text { Undergone } \\
\text { surgical } \\
\text { procedure }\end{array}$} & \begin{tabular}{|c|} 
Yes \\
\end{tabular} & 42.7 & 36.7 & 207 \\
\hline & No & 57.3 & 63.3 & 293 \\
\hline \multirow{2}{*}{ When surgery } & Within six months & 19.2 & 30.0 & 44 \\
\hline & Before six months & 80.8 & 70.0 & 163 \\
\hline \multirow{2}{*}{$\begin{array}{c}\text { Undergone } \\
\text { renal dialysis }\end{array}$} & \begin{tabular}{|c|} 
Yes \\
\end{tabular} & 1.5 & 1.8 & 8 \\
\hline & No & 98.5 & 98.2 & 492 \\
\hline \multirow{2}{*}{$\begin{array}{l}\text { Undergone } \\
\text { circumcision }\end{array}$} & Yes & 24.6 & 7.3 & 104 \\
\hline & No & 75.4 & 92.7 & 396 \\
\hline \multirow{2}{*}{$\begin{array}{c}\text { When } \\
\text { circumcision }\end{array}$} & Within six months & 19.8 & 100.0 & 19 \\
\hline & Before six months & 80.2 & 0 & 85 \\
\hline \multirow{2}{*}{$\begin{array}{c}\text { Dental } \\
\text { procedure }\end{array}$} & \begin{tabular}{|c|} 
Yes \\
\end{tabular} & 38.9 & 42.2 & 198 \\
\hline & \begin{tabular}{|c|} 
No \\
\end{tabular} & 61.1 & 57.8 & 302 \\
\hline \multirow{2}{*}{ When } & Within six months & 13.2 & 13.0 & 26 \\
\hline & Before six months & 86.8 & 87.0 & 172 \\
\hline \multirow{2}{*}{$\begin{array}{c}\text { Parenteral } \\
\text { drugs and } \\
\text { drips }\end{array}$} & \begin{tabular}{|c|} 
Yes \\
\end{tabular} & 43.5 & 52.3 & 227 \\
\hline & No & 56.5 & 47.7 & 273 \\
\hline \multirow{2}{*}{ When } & Within six months & 39.4 & 42.1 & 91 \\
\hline & Before six months & 60.6 & 57.9 & 136 \\
\hline \multicolumn{3}{|c|}{$\begin{array}{c}\text { Risk Factors related to Personal } \\
\text { Practices }\end{array}$} & & \\
\hline \multirow{2}{*}{$\begin{array}{c}\text { Hair cut/ } \\
\text { Shave in } \\
\text { barber shop }\end{array}$} & \begin{tabular}{|c|} 
Yes \\
\end{tabular} & 52.4 & 44.0 & 253 \\
\hline & No & 47.6 & 56.0 & 247 \\
\hline \multirow{2}{*}{ Share razors } & Yes & 2.3 & 0 & 9 \\
\hline & No & 97.7 & 100 & 491 \\
\hline \multirow{2}{*}{$\begin{array}{l}\text { Share tooth } \\
\text { brush }\end{array}$} & Yes & 1.5 & 0 & 6 \\
\hline & No & 98.5 & 100 & 494 \\
\hline \multirow{2}{*}{$\begin{array}{l}\text { Ear piercing } \\
\text { or tattooing }\end{array}$} & Yes & 7.4 & 1.8 & 31 \\
\hline & \begin{tabular}{|l|} 
No \\
\end{tabular} & 92.6 & 98.2 & 469 \\
\hline \multicolumn{3}{|c|}{$\begin{array}{c}\text { Risk Factors related to Personal } \\
\text { Behaviours }\end{array}$} & & \\
\hline \multirow{2}{*}{$\begin{array}{c}\text { Extra marital } \\
\text { or premarital } \\
\text { sex }\end{array}$} & \begin{tabular}{|c|} 
Yes \\
\end{tabular} & 4.1 & 1.8 & 18 \\
\hline & No & 95.9 & 98.2 & 482 \\
\hline \multirow{2}{*}{ Drug Use } & Yes & 2.0 & 0 & 8 \\
\hline & No & 98.0 & 100 & 492 \\
\hline Alcohol & Yes & 38.6 & 23.9 & 177 \\
\hline consumption & No & 61.4 & 76.1 & 323 \\
\hline & Daily & 45.7 & 65.4 & 86 \\
\hline Frequency & Sometimes & 50.3 & 26.9 & 83 \\
\hline & Rarely & 4.0 & 7.7 & 8 \\
\hline & Yes & 29.9 & 22.0 & 141 \\
\hline Smoking & No & 70.1 & 78.0 & 359 \\
\hline & Daily & 64.1 & 70.8 & 92 \\
\hline Frequency & Sometimes & 32.5 & 25.0 & 44 \\
\hline & \begin{tabular}{|c|} 
Rarely \\
\end{tabular} & 3.4 & 4.2 & 5 \\
\hline Ris & Factors related $t$ & o Other & ictors & \\
\hline & Yes & 8.4 & 15.6 & 50 \\
\hline Diabetic & No & 91.6 & 84.4 & 450 \\
\hline Family & Yes & 30.2 & 21.1 & 141 \\
\hline $\begin{array}{l}\text { member had } \\
\text { disease }\end{array}$ & No & 69.8 & 78.9 & 359 \\
\hline Earlier & Yes & 25.3 & 6.4 & 106 \\
\hline infection & No & 74.7 & 93.6 & 394 \\
\hline Vaccination & Yes & 0 & 33.0 & 36 \\
\hline against HBV & No & 100.0 & 67.0 & 464 \\
\hline
\end{tabular}


The epidemiology of HBV is complex in the sense that it occurs as percutaneous and permucosal exposure to infectious body fluids. ${ }^{12}$ Risk factors are grouped into four categories according to their exposure pattern. First group associated with health care related factors such as history of renal dialysis, undergone blood investigation, blood transfusion, ever had donated blood, had met an accident and blood loss, undergone a surgical procedure, dental procedure, parenteral drugs and drips. These factors are included if the incidence is within six months. The second group of exposure includes personal practices such as had a hair cut in barber shop, shared a razor, had shared tooth brush, ear piercing or tattooing. Third group of exposure is personal behaviour related risk factors which include having high-risk sexual behaviour, drug use or smoking and alcoholic consumption and fourth group or other related risk factors include prevalence of HBV among family members and earlier infection of HBV and being diabetic. Table 2 deals with the exposure of risk of patients.

\section{Hospital or Health Care Related Risk Factors}

HBV patients and control (with HBsAg negative) differ in their process of blood investigation. About 84 percent of the cases and 93 percent of the control had undergone a blood investigation. Out of these, about 62 percent of the cases and 74 percent of the control had undergone it within six months. Because being patients referred by other hospitals they already must have undergone blood investigation, which is the main reason for high percentage of blood investigation observed. More number of patients among control group ascertained that the disposable syringe is always used in an investigation than case group. About 42 percent of the cases and 58 percent of the control have received an injection and out of which 60 percent of it is within six months among cases and it is 54 percent among controls. Here, again the control group ascertained that disposable syringe is always used than case group. Blood transfusion is done more by cases than controls, but blood donation is done more by controls than by cases. While about 31 percent of the case group has met with an accident (out of these 47 percent within six months), only 12 percent of the control group has met with an accident (out of these only 15 percent within six month). Surgical procedure was undergone more by case group than by control group. Out of the 47 percent only 19 percent had done it within six months, but percent of control group has undergone surgery is about 37 percent, out of these 30 percent done in within six months. Renal dialysis is also done more by control group. While more than 24 percent of the cases has undergone circumcision (within six months only 20 percent), in control group 7.3 percent has undergone circumcision. Those who has undergone a dental procedure within six months is almost equal among the two groups. Parenteral drugs and drips are done more by control group than case group. For multivariate analysis, each of these variables are grouped into one or zero according to 'yes' or 'no' answer. When taken together, it is found that hospital related risk factors have accounted to 78.6 percent.

\section{Risk Factors Related to Personal Practices}

Community acquired risk factors like shaving from common barber shop is also a method of transmission. Case group is exposed more to shaving or hair cutting in a barber shop than control group. Shaving at a barber shop, sharing razors and tooth brush are not significant risk factors among control group. Ear piercing or tattooing is done more by case group than by control group. For multivariate analysis each of these variables are grouped into one or zero according to 'yes' or 'no' answer. When taken together it is found that personal risk factors accounted to 56.1 percent.

\section{Risk Factors Related to Personal Behaviours}

Extra or premarital relationship is maintained by 4 percent of the case group. It is less among control group. Similarly, drug use, consumption of alcohol and smoking are more among cases than control group. For multivariate analysis each of these variables are grouped into one or zero according to 'yes' or 'no' answer. When taken together it is found that behaviour related factor related to 42.4 percent.

\section{Risk Factors Related to Other Factors}

Being diabetic is one of the factors of risk, because they have to do blood investigations frequently. Diabetic cases are more among control group than case group. About 30 percent of the case group and 21 percent of the control group has had a family history of disease. More than one-fourth of the cases have an earlier infection, while it is only about 6 percent in the control group. No one has taken vaccination against HBV in the case group, while 33 percent of the control group has immunized against HBV. For multivariate analysis each of these variables are grouped into one or zero according to 'yes' or 'no' answer. When taken together it is found that other related risk factors accounted to 47.0 percent of the total respondents.

\begin{tabular}{|c|c|c|c|}
\hline Risk Factor & Odds Ratio & 95\% CI & P value \\
\hline \multicolumn{4}{|l|}{ Sex } \\
\hline Male & 2.121 & $1.30-3.45$ & 0.003 \\
\hline \multicolumn{4}{|l|}{ Female $\AA$} \\
\hline \multicolumn{4}{|l|}{ Type of House } \\
\hline \multicolumn{4}{|l|}{ Semi-Pucca® } \\
\hline Pucca & -0.432 & $0.251-0.742$ & 0.002 \\
\hline Kutcha & 2.101 & $0.93-4.76$ & 0.075 \\
\hline \multicolumn{4}{|l|}{ Religion } \\
\hline \multicolumn{4}{|l|}{ Christians $®$} \\
\hline Hindus & -0.578 & $0.304-1.10$ & 0.095 \\
\hline Muslims & 1.854 & $0.74-4.65$ & 0.188 \\
\hline \multicolumn{4}{|l|}{ Education } \\
\hline \multicolumn{4}{|l|}{$\begin{array}{l}\text { Primary and } \\
\text { Illiterate } \AA\end{array}$} \\
\hline $\begin{array}{c}\text { Professional and } \\
\text { Graduation }\end{array}$ & -0.812 & $0.376-1.754$ & 0.597 \\
\hline $\begin{array}{l}\text { Middle, High and } \\
\text { Intermediate } \\
\text { Education }\end{array}$ & 2.526 & $1.29-4.96$ & 0.007 \\
\hline \multicolumn{4}{|l|}{$\begin{array}{l}\text { Other Related } \\
\text { Factors }\end{array}$} \\
\hline \multicolumn{4}{|l|}{ No® } \\
\hline Yes & 1.595 & $0.99-2.57$ & 0.055 \\
\hline Constant & 1.965 & & 0.151 \\
\hline \multicolumn{4}{|c|}{ Table 3. Multivariate Analysis of Risk Factors of HBV } \\
\hline
\end{tabular}

For the multivariate analysis, the above four variables are included. Information on exposure to health care related risk factors within six months of the occurrence of the HBV is included in the analysis. Dependent variable is infection of 
HBsAg which is ' 0 ' for controls with HBsAg negative and ' 1 ' for HBsAg positive cases.

To determine the factors associated with HBV infection, logistic regression is applied. Table 3 is the final step in the Backward LR method of the logistic regression. The final step of the variables of the logistic accounted for only $13.88 \%$ of the total variables that could be explained by the association. Multivariate analysis reveals that widely known risk factors like health care related factors (blood donation within six months, had undergone surgical procedure within six months etc.) are eliminated before the final step. Demographic and social factors along with other related risk factors are found to be independently associated with HBV infection.

It is found that males have two times chance of having the infection than females (OR 2.1 at $\mathrm{p}<0.001$ ). With respect to Christians, Hindus have 43 percent less chance of getting infection. It is significant at $0.1 \%$ level. With respect to Christians, Muslims have 1.8 times chance of getting the viral infection (OR 1.85). Even though bivariate analysis shows a significant association between Muslim religion and positivity, it is not significant in the multivariate analysis. Also bivariate analysis shows that circumcision is more among cases than among controls. But there exists a significant negative relationship with Hindus. Respondents living in Pucca houses have 57 percent less chance of getting the HBV at $p<0.1$. But people belonging to Kutcha houses have two times chance of seropositivity. Likelihood of getting the infection is 2.5 times more among those educated intermediate and middle school than primary educated and illiterate. It is highly significant. Higher educated (professionally educated and graduated) has less chance of getting the infection. But it is not significant. The only one compound risk factor entered into the final step is 'other related risk factors' which include earlier infection of HBV, being diabetic and family history of hepatitis infection. It is found that the odds of being HBsAg is 1.6 times (significant level of 0.05 ) higher among those who were exposed to other related risk factors.

The lack of significant associations with health care related factors is surprising and may be due to prevention measures taken in hospitals to prevent such infections. However, in some private or informal sectors performance of unsafe invasive procedures is done and hence awareness programmes creating demand from public towards safety should be launched. Association of education is also somewhat surprising and may be due to large number of samples included in the intermediate, middle and high school level. One of the factors included in the compound variable 'other related risk factor' include family history of infection, which is a significant factor in the analysis. Promotion of HBV transmission among those who had an HBV infected family member has been observed in other studies. ${ }^{15,16} \mathrm{OR}$ value of contact with household carrier for exposure to HBV infection is 1.8 in one study in China. ${ }^{17}$ A community based study in Tamilnadu shows that OR of 1.4 associations with family history of HBV and HBsAg positivity. ${ }^{6}$ Odds of being infected are more among males, is consistent with other studies. In Los Angeles, ${ }^{18}$ men are more likely than women to test positive for HBsAg with OR of 1.67. In one Indian study also revealed that preponderance of men are apparent in all types of viral hepatitis infections. ${ }^{19}$ Male sex, being aged $<50$ years and having a history of hepatocellular carcinoma was found to be significantly associated with HBsAg positivity in Taiwan. ${ }^{13}$ The finding that persons belonging to pucca house are less likely and kutcha houses are more likely to have positivity of HBV is also corroborating with other studies. Living in pucca house shows that the standard of living is high and semi-pucca shows a middle level housing residence and kutcha house considered as a low standard of living category. Many studies ${ }^{11,12}$ show that HBsAg is associated with socioeconomic status of the patients. Religion is also independently associated with HBV and Hindus are less likely to getting the infection than other major religious groups. Many studies highlighted the religious or ethnicity relationship with HBV. Probability of getting HBV is more among Muslims, which may be due to the cultural tradition of circumcision. Bivariate analysis of this study shows that circumcision is more among cases than among controls. Circumcision is found to be a significant factor of HBV is evident in other countries. ${ }^{14}$

The study has elucidated the factors of HBV infection by analysing data of 500 patients attending OP Unit in Govt. Medical College, Thiruvananthapuram, Kerala during 20122014. Out of the 500 patients, 391 are HBsAg positive (cases) and 109 are HBsAg negative patients (controls). Asymptomatic individuals referred to the unit from other peripheral hospitals or clinics during the study period are the respondents. The cases are patients with various forms of liver disease who tested positive for Hepatitis B surface (HBsAg) and controls are patients with HBsAg negative attending the same OP. The control subjects are matched for age and sex with cases.

In the study, it is revealed that the patients with HBV and controls (with HBsAg negative) have equal mean age and age at marriage and are almost equally distributed among age groups. Among males more are in HBsAg positive group, but females are equally distributed in the two groups. Religious composition reveals that HBsAg patients are more among Muslim population, but wide variation in percentages in Hindus which is more in control group. Behaviours negatively associated with health like consumption of alcohol, smoking and drug use are more among case group (with HBsAg positive) than among controls (with HBsAg negative).

Analysis reveals that majority of the respondents are not immunized. Since the disease is highly infective but preventable, awareness and prevention are factors of importance. It is also revealed that 10 percent of the respondents in the study are diabetic and they require blood investigations more frequently which is a risk factor of spreading the virus. In a society like Kerala, where lifestyle diseases are higher and majority of these people are utilising health care facilities, chance of transmission through blood is more. Private labs and clinics should be monitored whether safety is ensured in lab tests and injections. Transmission results from exposure to so many factors like infectious secretions, needles, unprotected sexual contacts and vertical transmission from mother to child during child birth etc. This case control study with HBV infection revealed that several high-risk behaviours and practices for the transmission of this infection are significantly more prevalent among the HBsAg positive patients compared to the controls. This means that parenteral transmission of HBV through these high-risk activities may have substantial contribution to disease burden. But multivariate analysis shows that one indexed variable namely other related risk factor which is a combination of 'earlier infection of HBV, being diabetic and family history of 
HBV' is significantly related with infection of HBV. Bivariate analysis shows that controls (HBsAg negative group) are more diabetic than cases (HBsAg patients) and being undergone blood investigations are more among controls than cases. This shows that this variable (being diabetic) is not associated with risk exposure. Other two variables are earlier infection and had a family history are more among cases than controls. Hence, these variables are significantly associated with virus infection. Health care related factors like history of renal dialysis, blood investigation, blood transfusion, ever had donated blood, had met an accident and blood loss, undergone a surgical procedure, dental procedure, parenteral drugs and drips are not significantly associated with HBV infection may be due to the effective infection control functions of the hospital. In 1993, one study 20 in the same hospital reported that reuse of needles was found to be the most important risk factor of the acquisition of hepatitis B. Such studies might be the reason for the effective control of such factors in the hospital. There were more instances of family history of liver disease among the cases compared to the controls. Hepatitis B virus infection has long been recognised to exhibit horizontal transmission among parents, children, siblings and other household members. Immunization status has revealed that case group had no one immunized, which shows the importance of the stressing vaccination against Hepatitis B. Transmission through blood pathogens is relatively weak in the model, which implies better and developed health care practices in Kerala. Significant relationship with socioeconomic factors like being male, living in kutcha houses and having lesser education are associated with HBV infection as found in other studies from other parts of India.10,11 Even though this study revealed a significant association with religion, but other Indian studies does not reveal such relation. Multivariate analysis reveals that earlier infection of HBV and family history of HBV are related to HBV infection and the variables entered into the model explained only 14 percent variation in the model. Hence, other variables associated with community or personal factor should be investigated. There is a paucity of population-based epidemiological information regarding hepatitis B virus (HBV) infection in India and Kerala is no exception. Hence, a community-based epidemiological study of HBV infection is needed to outline the magnitude and pattern of HBV infection, and the associated determinants in Kerala.

Moreover, due to the costly treatment of Hepatitis B infection and life-threatening complications, the preventive aspect is most important in combating the infection that should include creating awareness, early diagnosis and immunization, compliance with universal precautions.

\section{Limitations}

Since the hospital is a Government tertiary hospital situated in the Capital city, its reach is wider covering all parts of Kerala. However, there are limitations because hospital-based studies are prone to selection bias ${ }^{21}$ and community wide inferences cannot be made.22 Hence, no association of personal practices, community practices and hospital-based risk factors are included.

\section{DISCUSSION}

The study has elucidated the factors of HBV infection by analysing data of 500 patients attending OP unit in Govt.
Medical College, Thiruvananthapuram, Kerala during 20122014. Out of the 500 patients, 391 are HBsAg positive (cases) and 109 are HBsAg negative patients (controls). Asymptomatic individuals referred to the unit from other peripheral hospitals or clinics during the study period are the respondents. The cases are patients with various forms of liver disease who tested positive for Hepatitis B surface (HBsAg) and controls are patients with HBsAg negative attending the same OP. The control subjects are matched for age and sex with cases.

In the study, it is revealed that the patients with $\mathrm{HBV}$ and controls (with HBsAg negative) have equal mean age and age at marriage and are almost equally distributed among age groups. Among males more are in HBsAg positive group, but females are equally distributed in the two groups. Religious composition reveals that HBV patients are more among Muslim population, but wide variation in percentages in Hindus which is more in control group. Behaviours negatively associated with health like consumption of alcohol, smoking and drug use are more among case group (with HBV positive) than among controls (with HBsAg negative).

Analysis reveals that majority of the respondents are not immunized. Since the disease is highly infective but preventable, awareness and prevention are factors of importance. It is also revealed that 10 percent of the respondents in the study are diabetic and they require blood investigations more frequently which is a risk factor of spreading the virus. In a society like Kerala where lifestyle diseases are higher and majority of these people are utilising health care facilities, chance of transmission through blood is more. Private labs and clinics should be monitored whether safety is ensured in lab tests and injections. Transmission results from exposure to so many factors like infectious secretions, needles, unprotected sexual contacts and vertical transmission from mother to child during child birth etc. This case control study with HBV infection revealed that several high-risk behaviours and practices for the transmission of this infection are significantly more prevalent among the HBV positive patients compared to the controls. This means that parenteral transmission of HBV through these high-risk activities may have substantial contribution to disease burden. But multivariate analysis shows that one indexed variable namely other related risk factor which is a combination of 'earlier infection of HBV, being diabetic and family history of HBV' is significantly related with infection of HBV. Bivariate analysis shows that controls (HBsAg negative group) are more diabetic than cases (HBV patients) and being undergone blood investigations are more among controls than cases. This shows that this variable (being diabetic) is not associated with risk exposure. Other two variables are earlier infection and had a family history are more among cases than controls. Hence, these variables are significantly associated with virus infection. Health care related factors like history of renal dialysis, blood investigation, blood transfusion, ever had donated blood, had met an accident and blood loss, undergone a surgical procedure, dental procedure, parenteral drugs and drips are not significantly associated with HBV infection may be due to the effective infection control functions of the hospital. A study in the same hospital settings reported that reuse of needles was found to be the most important risk factor of the acquisition of hepatitis B20. The findings of such studies have perhaps led to the effective control of such factors in the control group. There were more instances of family 
history of liver disease among the cases compared to the controls. Hepatitis B virus infection has long been recognised to exhibit horizontal transmission among parents, children, siblings and other household members. Immunization status has revealed that case group had no one immunized, which shows the importance of the stressing vaccination against Hepatitis B. Significant relationship with socioeconomic factors like being male, living in kutcha houses and having lesser education are associated with HBV infection as found in other studies from other parts of India.10,11 Even though this study revealed a significant association with religion, other Indian studies does not reveal such relation. Multivariate analysis reveals that earlier infection of $\mathrm{HBV}$ and family history of HBV are related to HBV infection and the variables entered into the model explained only 14 percent variation in the model. Hence, other variables associated with community or personal factor should be investigated. There is a paucity of population-based epidemiological information regarding hepatitis B virus (HBV) infection in India and Kerala is no exception. Hence, a community-based epidemiological study of HBV infection is needed to outline the magnitude and pattern of HBV infection and the associated determinants in Kerala. Moreover, due to the costly treatment of Hepatitis B infection and life-threatening complications, the preventive aspect is most important in combating the infection that should include creating awareness, early diagnosis and immunization, compliance with universal precautions.

\section{CONCLUSION}

The study revealed that there were more instances of family history of liver disease among the cases compared to the controls. Hepatitis B virus infection has long been recognised to exhibit horizontal transmission among parents, children, siblings and other house-hold members. Immunization status has revealed that case group had no one immunized, which shows the importance of the stressing vaccination against Hepatitis B. Transmission through blood pathogens is relatively weak in the model, which implies better and developed health care practices in Kerala.

\section{REFERENCES}

[1] World Health Organisation (WHO). Hepatitis B and C Immunization, Vaccines and Biologicals. 2013. http://www.who.int/immunization/topics/hepatitis/ en/

[2] Dhir V, Mohandas KM. Epidemiology of digestive tract cancers in India. Southeast Asian J Trop Med Public Health 1997;28:699-706.

[3] Singh K, Bhat S, Shastry S. Trend in seroprevalence of Hepatitis B virus infection among blood donors of coastal Karnataka, India. The Journal of Infection in Developing Countries 2009;3(5):376-9.

[4] Alter MJ, Ahtone J, Weisfuse I, et al. Hepatitis B virus transmission between heterosexuals. JAMA 1986;256(10):1307-10.

[5] Ganem D, Prince AM. Hepatitis B virus infection natural history and clinical consequences. $\mathrm{N}$ Engl J Med 2004;350(11):1118-29.

[6] Kurien T, Thyagarajan SP, Jeyaseelan L, et al. Community prevalence of hepatitis B infection \& modes of transmission in Tamil Nadu, India. Indian Journal of Medical Research 2005;121(5):670-5.
[7] Batham A, Narula D, Toteja T, et al. Systematic review and meta-analysis of prevalence of hepatitis $B$ in India. Indian Pediatr 2007;44(9):663-74.

[8] Mahoney FJ. Update on diagnosis, management and prevention of hepatitis $\mathrm{B}$ virus infection. Clinical Microbiology Reviews 1999;12(2):351-66.

[9] Qirbi N, Hall AJ. Epidemiology of hepatitis B virus infection in the Middle East. Eastern Mediterranean Health Journal 2001;7(6):1034-45.

[10] Jayaprakash PA, Shanmugam J, Hariprasad D. Hepatitis $B$ surface antigen in blood donors. Transfusion 1983;23(4):346-7.

[11] Chowdhury A, Santra A, Chakravorty R, et al. Community-based epidemiology of hepatitis $\mathrm{B}$ virus infection in West Bengal, India: prevalence of hepatitis $B$ e antigen-negative infection and associated viral variants. Journal of Gastroenterology and Hepatology 2005;20(11):1712-20.

[12] Afzal S, Basheer M. Determinants for transmission of hepatitis B and C. Annals of King Edward Medical University 2009;15(4).

[13] Wang CS, Chang TT, Yao WJ, et al. Comparison of hepatitis $B$ virus and hepatitis $C$ virus prevalence and risk factors in a community-based study. Am J Trop Med Hyg 2002;66(4):389-93.

[14] Ashraf H, Alam NH, Rothermundt C, et al. Prevalence and risk factors of hepatitis $\mathrm{B}$ and $\mathrm{C}$ virus infections in an impoverished urban community in Dhaka, Bangladesh. BMC Infectious Diseases 2010;10:208. http://dx.doi.org/10.1186/1471-2334-10-208.

[15] Talaat M, Radwan E, El-Sayed N, et al. Case-control study to evaluate risk factors for acute hepatitis B virus infection in Egypt. EMHJ 2010;16(1):4-9.

[16] Nwokediuko S. Risk factors for hepatitis B virus transmission in Nigerians: a case-control study. The Internet Journal of Gastroenterology 2010;10(1):1-5.

[17] Ji Z, Wang T, Shao Z, et al. A population-based study examining hepatitis $B$ virus infection and immunization rates in Northwest China. PLoS One 2014;9(5):e97474. https://doi.org/10.1371/journal.pone.0097474

[18] Barragan NC, Chang M, Felderman J, et al. A case study of a hepatitis $\mathrm{b}$ screening and blood pressure assessment program in Los Angeles County, 20122013 preventing chronic disease. Prev Chronic Dis 2015;12:140373.

[19] Thrivikram T, Rahman A, Kalyani D, et al. Epidemiology and burden of viral hepatitis: hospital based study. Journal of Dental and Medical Sciences (IOSR-JDMS) 2016;15(4):54-8.

[20] Narendranathan M, Philip M. Reusable needles - a major risk factor for virus B hepatitis. Trop Doct 1993;23(2):64-6.

[21] Berkelman RL, Stroup DF, Buehler JW. Chapter 6. 16. Public health surveillance. In: Detels R, McEwen J, Beaglehole R, et al. eds. Oxford textbook of public health. Vol 2. $4^{\text {th }}$ edn. Oxford: Oxford University Press 2002:759-78.

[22] Steinwachs DM. Management information in decision making. Chap - 4. In: Haroutune K, Armenian K, Shapiro S. eds. Epidemiology and health services. Part II. New York: Oxford University Press 1998:41-60. http://www.biomedcentral.com/1471-2334/10/208. 